\title{
Winter Weed Emergence during Carinata (Brassica carinata) Production ${ }^{1}$
}

\author{
Ruby Tiwari, Pratap Devkota, and Michael J. Mulvaney ${ }^{2}$
}

This publication is targeted to county UF/IFAS Extension agents and growers to provide an overview of winter weed emergence timing in relation to the cumulative growing degree days (GDD) and carinata (Brassica carinata) growth stages in Florida. The information presented is a summary of research conducted at the UF/IFAS West Florida Research and Education Center in Jay, FL. This publication provides information for predicting emergence timing of common winter weed species for carinata production and will aid in implementing control measures in a timely manner.

\section{Background}

Recently, carinata has been promoted as an oilseed crop for biofuel production. In the southeastern United States, carinata is planted in late fall, grown throughout the winter, and harvested the following year in late spring to early summer (Seepaul et al. 2019). Multiple winter weed species can be a problem during carinata production. Chickweed (Stellaria media)is a common winter weed, which is widely distributed throughout the southeastern United States. It emerges throughout the winter season from late fall to early spring (Figure 1). Likewise, cutleaf evening-primrose (Oenothera laciniata) (Figure 2)and henbit (Lamium amplexicaule) (Figure 3) are two more problematic winter annual weeds for cool-season crops in the southeastern United States. (Webster and MacDonald 2001).

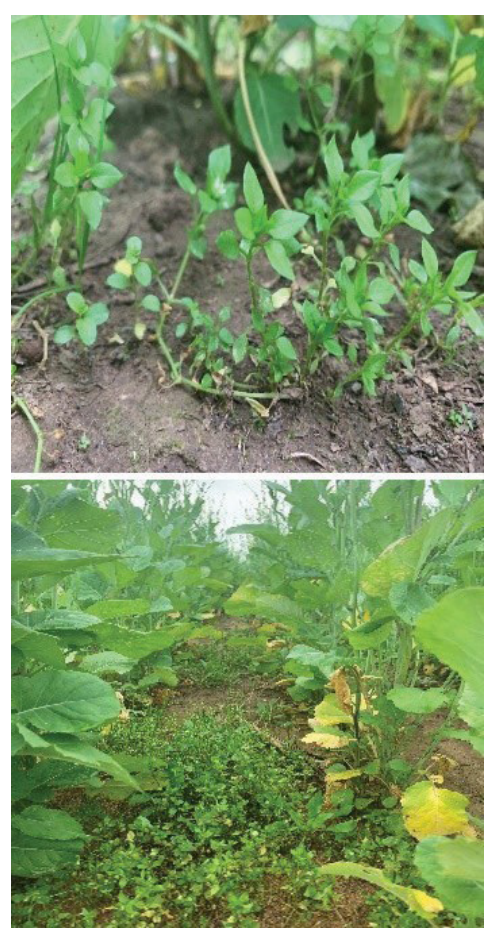

Figure 1. Chickweed growing adjacent to carinata near Jay, Florida. Credits: Ruby Tiwari

Carinata exhibits slow early-season growth; therefore, weed control measures during early crop growth are necessary to prevent yield loss. Prediction of the timing of weed emergence in relation to critical crop growth stages is important for weed control. Environmental conditions such as temperature influence weed emergence timing; thus,

1. This document is SS-AGR-454, one of a series of the Agronomy Department, UF/IFAS Extension. Original publication date June 2021. Visit the EDIS website at https://edis.ifas.ufl.edu for the currently supported version of this publication.

2. Ruby Tiwari, master's student, UF/IFAS Southwest Florida Research and Education Center; Pratap Devkota, assistant professor, weed science, UF/IFAS West Florida Research and Education Center; and Michael J. Mulvaney, associate professor, cropping systems, UF/IFAS WFREC; UF/IFAS Extension, Gainesville, FL 32611.

The Institute of Food and Agricultural Sciences (IFAS) is an Equal Opportunity Institution authorized to provide research, educational information and other services

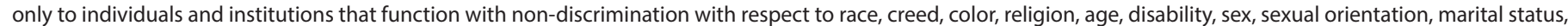

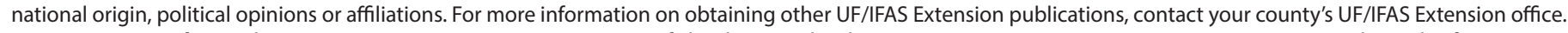
U.S. Department of Agriculture, UF/IFAS Extension Service, University of Florida, IFAS, Florida A \& M University Cooperative Extension Program, and Boards of County Commissioners Cooperating. Nick T. Place, dean for UF/IFAS Extension. 
temperature should be considered for planning and implementing weed management strategies (Hill et al. 2014). Emergence of weed species is commonly described using accumulated GDD. The GDD, also known as heat units, incorporates the average daily temperature accumulation by a crop or weed species. It is widely used and is a more reliable method than days after planting for estimating emergence and development stages of crops and weeds. For weeds, GDD is particularly important for determining emergence thresholds (percent) and implementing control strategies in a timely manner.
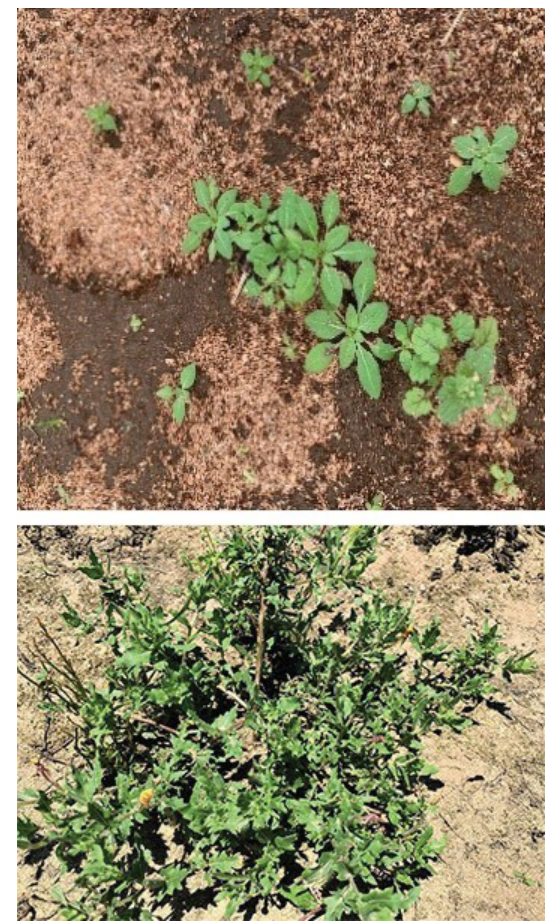

Figure 2. Cutleaf evening-primrose seedling established in the field and mature plant with flower.

Credits: Ruby Tiwari and Pratap Devkota

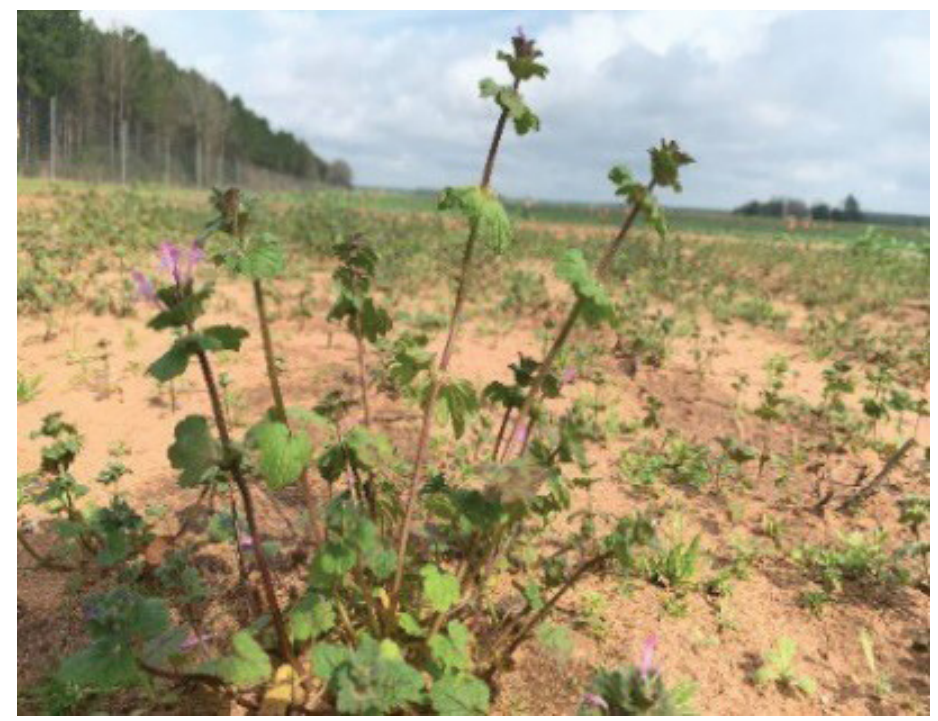

Figure 3. Henbit growing in a field near Jay, Florida.

Credits: Ruby Tiwari

\section{Winter Weed Emergence and Carinata Growth Stages}

Winter weed emergence patterns were determined through carinata research during the 2019-2020 season at the UF/ IFAS West Florida Research and Education Center in Jay, FL. Cumulative emergence for the winter weed species (chickweed, cutleaf evening-primrose, and henbit) were calculated as a percent of total emergence. Weed emergence was described using cumulative growing degree days (GDD):

\section{$G D D=\sum_{i=1}^{n}\left(T_{\text {mean }}-T_{\text {base }}\right)$}

where represents the daily average soil temperature in degrees Celsius $\left({ }^{\circ} \mathrm{C}\right)$, and is the minimum temperature at which chickweed, cutleaf evening-primrose, and henbit seeds germinate. Base temperatures of $10^{\circ} \mathrm{C}$ for chickweed and $0^{\circ} \mathrm{C}$ for cutleaf evening-primrose and henbit were used for GDD calculation. For carinata GDD calculation, $5^{\circ} \mathrm{C}$ was used as the base temperature (i.e., based on winter canola) and important growth stages were recorded.

\section{Cumulative GDD and Winter Weed Emergence}

Total chickweed emergence was 25\% at 100 GDD (Table 1) and $50 \%$ at $250 \mathrm{GDD}$. Cumulative GDD was $350-400$ for chickweed at $75 \%$ emergence, while GDD was about double that for $100 \%$ emergence. For cutleaf evening-primrose and henbit, GDDs were nearly double that of chickweed for the same level of emergence (Table 1). These two weed species showed $25 \%, 50 \%$, and $90 \%$ emergence at $250,500-700$, and 1,000-1,200 GDD, respectively. Henbit and cutleaf evening-primrose showed $100 \%$ emergence after 1,300 GDD.

\section{Cumulative GDD and Carinata Growth Stages}

Carinata reached the 2- to 3-leaf stage at 200 GDD (Table 2) and the 4- to 5-leaf stage at $400 \mathrm{GDD}$. After the 4- to 5-leaf stage, however, carinata required only an additional 100 GDD (i.e., cumulative GDD of 500) to reach the 8- to 10 -leaf stage. Early bolting occurred at 750 GDD. At 1,000 GDD, carinata reached $50 \%$ flowering, and pod fill to maturity occurred at 1,300-2,000 GDD. 


\section{Winter Weed Emergence in Relation to Carinata Growth Stage}

Chickweed emergence was $50 \%$ when carinata was approximately at the 2 - to 3 -leaf stage (Table 3 ). About $75 \%$ of total chickweed emergence occurred by the time carinata was at the 4 - to 5 -leaf stage. The remaining $25 \%$ of the total emergence occurred when carinata was between the 5- to 6-leaf stage through early bolting. The emergence of cutleaf evening-primroseand henbit was only $25 \%$ when carinata reached the 4-leaf stage (Table 3). These two weed species reached $50 \%$ and $75 \%$ emergence when carinata was at the 10- to 12-leaf stage through late bolting, respectively. For these weed species, $90 \%$ of emergence occurred by $50 \%$ flowering of carinata.

Crop growth stage is an important aspect to consider when implementing weed control. Spring canola, botanically similar to carinata, should be kept weed-free until the 4- to 6-leaf stage in order to prevent yield loss (Martin et al. 2001). Our results illustrated that the majority of chickweed emergence occurred during early carinata growth, whereas the majority of cutleaf evening-primrose and henbit emergence occurred between the late vegetative to early flowering stages of carinata. Therefore, it is recommended to implement chickweed control measures during early carinata growth (i.e., by the 4- to 6-leaf stage). Likewise, cutleaf evening-primrose and henbit should be managed prior to carinata flowering, not only for improved control but also because of field access. Moreover, effective control strategies need to be implemented with appropriate timing to control these as well as other problematic weed species.

\section{Conclusion}

Carinata growers need to consider timing for optimal winter weed control. The relationship between GDD, winter weed emergence, and carinata growth should be considered as part of an integrated weed management program. Utilize appropriate herbicide programs or other tools to control weeds in a timely manner to prevent weed competition at critical crop growth stages.

\section{References}

Hill, E. C., K. A. Renner, and C. L. Sprague. 2014. "Henbit (Lamium amplexicaule), Common Chickweed (Stellaria media), Shepherd's Purse (Capsella bursa-pastoris), and Field Pennycress (Thlaspi arvense): Fecundity, Seed Dispersal, Dormancy, and Emergence." Weed Science 62:97-106. https://doi.org/10.1614/WS-D-13-00074.1
Martin, S. G., R. C. Van Acker, and L. F. Friesen. 2001. "Critical Period of Weed Control in Spring Canola.” Weed Science 49:326-333. https://doi. org/10.1614/0043-1745(2001)049[0326:CPOWCI]2.0.CO;2

Seepaul, R., I. M. Small, M. J. Mulvaney, S. George, R. G. Leon, S. V. Paula-Moraes, D. Geller, J. J. Marois, and D. L. Wright. 2019. Carinata, the Sustainable Crop for a Bio-Based Economy: 2018-2019 Production Recommendations for the Southeastern United States. SS-AGR-384. Gainesville: University of Florida Institute of Food and Agricultural Sciences. https://edis.ifas.ufl.edu/ag389

Webster, T. M., and G. E. MacDonald. 2001. "A Survey of Weeds in Various Crops in Georgia." Weed Technology 15:771-790. https://doi.org/10.1614/0890-037X(2001)0 15[0771:ASOWIV]2.0.CO;2 
Table 1. Winter weed emergence (\%) predicted by cumulative growing degree days (GDD) during carinata production in Jay, FL.

\begin{tabular}{|c|c|c|c|c|c|}
\hline Weed Species & 25\% Emergence & 50\% Emergence & 75\% Emergence & 90\% Emergence & $100 \%$ Emergence \\
\hline & \multicolumn{5}{|c|}{ 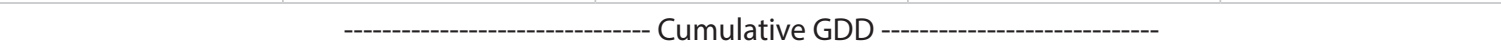 } \\
\hline Chickweed & 100 & 250 & $350-400$ & 500 & $600-900$ \\
\hline $\begin{array}{l}\text { Cutleaf evening- } \\
\text { primrose }\end{array}$ & 250 & $500-700$ & $800-900$ & $1,000-1,200$ & $1,300-2,000$ \\
\hline Henbit & 250 & $500-700$ & $800-900$ & $1,000-1,200$ & $1,300-2,000$ \\
\hline
\end{tabular}

Table 2. Carinata growth stages corresponding to cumulative growing degree days (GDD) during carinata production in Jay, FL.

\begin{tabular}{|c|c|}
\hline Cumulative GDD & Carinata Growth Stage \\
\hline 150 & 1- to 2-leaf \\
\hline 200 & 2- to 3-leaf \\
\hline 400 & 4 - to 5-leaf \\
\hline 500 & 8 - to 10-leaf \\
\hline 750 & Early bolting \\
\hline 1,000 & $50 \%$ flowering \\
\hline $1,300-2,000$ & Pod fill to maturity \\
\hline
\end{tabular}

Table 3. Winter weed emergence in relation to carinata growth stage at Jay, FL.

\begin{tabular}{|c|c|c|c|c|c|}
\hline \multirow[t]{2}{*}{ Weed Species } & \multicolumn{5}{|c|}{ Carinata Growth Stage } \\
\hline & $\begin{array}{l}\text { At } 25 \% \text { Weed } \\
\text { Emergence }\end{array}$ & $\begin{array}{l}\text { At } 50 \% \text { Weed } \\
\text { Emergence }\end{array}$ & $\begin{array}{l}\text { At } 75 \% \text { Weed } \\
\text { Emergence }\end{array}$ & $\begin{array}{l}\text { At } 90 \% \text { Weed } \\
\text { Emergence }\end{array}$ & $\begin{array}{l}\text { At } 100 \% \text { Weed } \\
\text { Emergence }\end{array}$ \\
\hline Chickweed & 1- to 2-leaf & 2- to 3-leaf & 4- to 5-leaf & 10 - to 12 -leaf & Early bolting \\
\hline $\begin{array}{l}\text { Cutleaf evening- } \\
\text { primrose }\end{array}$ & 3- to 4-leaf & 10- to 12-leaf & Late bolting & $50 \%$ flower & Pod fill \\
\hline Henbit & 3- to 4-leaf & 10- to 12 -leaf & Late bolting & $50 \%$ flower & Pod fill \\
\hline
\end{tabular}

